\title{
Communal Public Space Management Under Social Network Horizon
}

\author{
-Taking an example of old blocks of eight immortals palace in Xi'an
}

\author{
Gao Yushan \\ School of human scttlements and civil engineering of \\ $\mathrm{Xi}$ 'an Jiaotong university \\ $\mathrm{Xi}$ 'an, China \\ E-mail: archgys@126.com
}

\author{
Zhao Yiqing \\ School of human scttlements and civil engineering of \\ $\mathrm{Xi}$ 'an Jiaotong university \\ Institute of heritage sites\&historical architecture \\ conservation of Xi 'an Jiaotong university \\ Xi 'an, China \\ E-mail: zyq_005177@163.com
}

\author{
Xu Jian \\ School of human scttlements and civil engineering of \\ $\mathrm{Xi}$ 'an Jiaotong university \\ Institute of heritage sites\&historical architecture \\ conservation of Xi 'an Jiaotong university \\ Xi 'an, China \\ E-mail: jian.xu007@163.com
}

\author{
Zhang Rui \\ School of human scttlements and civil engineering \\ of Xi 'an Jiaotong university \\ Xi 'an, China \\ E-mail:zhangruiruby@163
}

\begin{abstract}
This study takes older blocks around the eight immortals palace in Dongguan of $x i$ 'an as an example to explore the comparison and validation of integration of community public space in the old city with the classification prototype, and then puts forward strategies for the space management. Based on the social network, public space of eight immortals palace old blocks is studied by combining the residential planning theory and related theory of space syntax, which can guide the public space governance for the old bocks and make them self-renewal. This paper tries to use this method for old blocks space integration. Public space structure adapt to the requirement of the public activ integration can make the old blocks maintain its vitality, thus extends the social memory of old blocks residents, and keeps distinctive living forms. Moreover, that plays an positive role in preserving urban memory. At the same time, this research also has certain limitations. There are many historic blocks in the eight immortals palace area. The eight immortals palace as a cultural heritage is bearing the weight of the memory of people, but it remains to be further discussed for its relationship with the old blocks update.
\end{abstract} words)

Keywords-component; formatting; style; styling; insert (key

\section{INTRODUCTION}

With the urban development in our country, living conditions of residents are continuously improved, old blocks formed in economic backwardness period show two kinds of trends: most of the old blocks are gradually broken due to residents' fleeing; the small part of old blocks are gradually self-renewal with higher popularity. It is worth noting the two trends in old blocks dominated by residents' spontaneous behavior, except upper planning and real estate development. Residents have social attribute, purpose of their spontaneous behavior is to maintain social network. And maintaining social network needs a variety of social activities, to which public spaces are behavior containers to correspond. According to different social activities, residents choose different public spaces, which produces public space structure spontaneously created by residents. Social activities within community are an important part of modern residents' daily life. Under the background of Dongguan area old city renewal projects dominated by xi 'an Beilin district government in 2014, the author chooses eight immortals palace in eight immortals area of the oldest old blocks as research center, delimiting $500^{1} \mathrm{~m}$ as radius (Figure 1.). The author observes seven old blocks within this scope and finds that public spaces in old block beginning to decline have abundant forms and faintly form the classification protype $^{2}$, and residents' social activities are relatively abundant.

On balance ,the author puts forward: the old blocks is one kind of community forms, and the core question of improving old block is to govern public space and make it adaptable with residents public activities demands so as to keeping update vitality. At the same time, comparing with seven old blocks, the author concludes characteristics of old block spaces with self-renewal basis and puts forward

\footnotetext{
${ }^{1}$ The author put forward the noun, refers to the public space classification in shanty towns formed by actual use of frequency and the difference of the number of residents.

${ }^{2}$ The author put forward the noun, refers to the public space classification in shanty towns formed by actual use of frequency and the difference of the number of residents.
} 
the thinking to govern old block spaces by using original words.

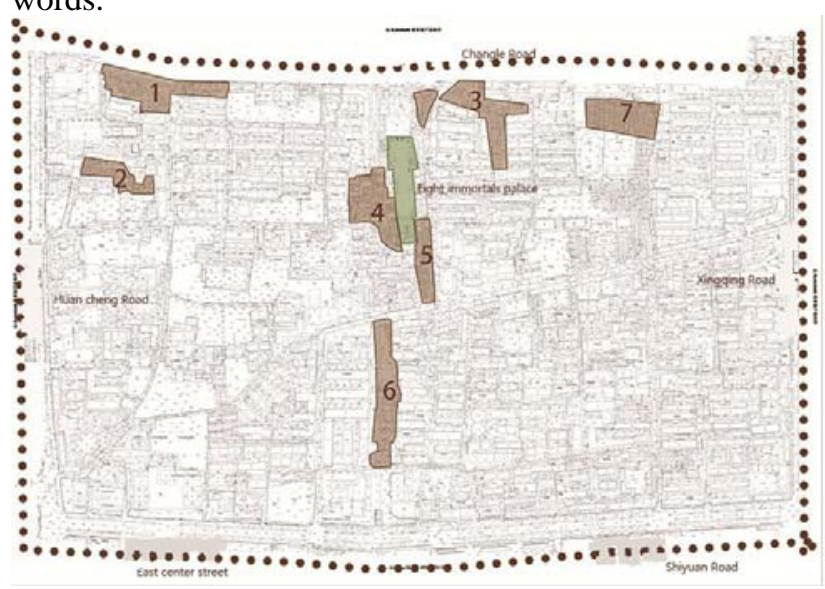

Figure 1. Research scope (from drawing of project team)

\section{THEORY BASIS}

\section{A. Planning for Residential Area}

The latest community planning mode takes community public space as the necessary element, and divides public spaces into three levels: residential district, residential community, team and group. Roads to link public spaces are divided into four levels: residential district roads, community roads, team and group roads, roads in front of the housing. Different levels of public spaces and roads fit residents' different social activities as well as different integration degrees of public spaces.

TABLE 1. CLASSIFICATION OF DIFFERENT PUBLIC SPACE

\begin{tabular}{|l|l|l|l|l|}
\hline $\begin{array}{c}\text { Public space } \\
\text { level }\end{array}$ & $\begin{array}{l}\text { Road } \\
\text { level }\end{array}$ & $\begin{array}{l}\text { Service } \\
\text { object }\end{array}$ & $\begin{array}{l}\text { Activity } \\
\text { content }\end{array}$ & $\begin{array}{l}\text { Integration } \\
\text { degree }\end{array}$ \\
\hline $\begin{array}{l}\text { Public space } \\
\text { with } \\
\text { residential } \\
\text { district level }\end{array}$ & $\begin{array}{l}\text { Road } \\
\text { with } \\
\text { resident } \\
\text { ial } \\
\text { district } \\
\text { level }\end{array}$ & $\begin{array}{l}\text { District } \\
\text { residents, } \\
\text { city }\end{array}$ & $\begin{array}{l}\text { City } \\
\text { activity }\end{array}$ & High \\
\hline $\begin{array}{l}\text { Public space } \\
\text { with } \\
\text { residential } \\
\text { community } \\
\text { level }\end{array}$ & $\begin{array}{l}\text { Road } \\
\text { with } \\
\text { resident } \\
\text { ial } \\
\text { commu } \\
\text { nity }\end{array}$ & $\begin{array}{l}\text { Residenti } \\
\text { al district } \\
\text { residents }\end{array}$ & $\begin{array}{l}\text { Neighborh } \\
\text { ood } \\
\text { association }\end{array}$ & Higher \\
\hline $\begin{array}{l}\text { Public space } \\
\text { with team and } \\
\text { group level }\end{array}$ & $\begin{array}{l}\text { Team } \\
\text { and } \\
\text { group } \\
\text { road }\end{array}$ & $\begin{array}{l}\text { Residenti } \\
\text { al district } \\
\text { residents }\end{array}$ & $\begin{array}{l}\text { Neighborh } \\
\text { ood } \\
\text { association }\end{array}$ & Lower \\
\hline
\end{tabular}

\section{B. Social Network}

British anthropologist Radcliffe•brown first used the concept of "social network" (XiaoHong, 1999, the sociological study (3): 1). Social network is all formal and informal social contacts forming by a person with the others , which also includes direct social relations between people and indirect relation through sharing with physical environment and culture. Social network a relatively stable social structure composed of nodes and links, of which the node refers to individual or organization and the link refers to the social relation formed by interactive communication
(Chen Jingmin, 2012, master degree theses of South China University of Technology). It can be understood for the connotation of social network in old blocks that the set constituted by the relation among community residents forms original social network of old blocks. Social network is the material carrier of social capital, and social capital is performance results of social network. In the renewal and transformation of old blocks, social capital and social play an great importance in reviving of the old blocks. Integration of public spaces in old blocks is beneficial to revitalize original social network in old blocks, and form a new social network. Simultaneouly, the formation and revitalization of social networks are beneficial to the development of public spaces in old blocks.

\section{Space Syntax}

\section{1)Space syntax theory}

In 1984, Bill Healy of Bentley's school discussed law of spatial construction and established space theory on the basis of quantitative research-space syntax. The theory thinks that space as the component of social life is the theory and method for studying space organization and social relationship between people. The core content of the theory mainly includes two aspects: space is the place for activities and contacts of people, and has self-organizing ability; syntax composed of space has complexity which is the manifestation of society logic in urban space, and it is in harmony with built environment and is hard to express. In recent years, the theory is widely used in urban design. The author thinks that the theory has great application value for urban spaces which contains many social factors, such as old blocks.

\section{2) Model construction}

Four urban secondary main roads form closed graph in eight immortals palace, which separates residential area from other urban spaces. In addition to old blocks, there only commercial lands and eight immortals palace backward square are left for residents to go freely. And interaction is not strong in schools, enclosed residential area as well as old blocks residents, so convex space that can be analyzed includes old blocks public space, commercial land and residential district road. Axis model is obtained by importing convex space figure into depthmap software.

\section{3) Spatial analysis method}

Through axis model, space users can be better understood. This paper simulates residents usage situation within old blocks by using method of axis analysis. The meaning of integration is that a corresponding integration value is used to depict degree of convenience in each space, spatial accessibility and the possibility chosen as a travel destination, and its aggregation or discrete degree with other space. Integration has different analysis radius. Local integration $(\mathrm{R}=3)$ describes the possibility that every space reaches the other spaces within its topology distance in the space system, and studies traveler scope for walking (Guo Xiang fujian, Quanshui, 2013, Journal of architecture, (S2): 8 to 13). This paper uses software to calculate local integration of old blocks public space and combines principle of residential area planning to judge whether local integration of old blocks public space meets residents' requirements or not. 


\section{ANALYSIS OF OLD BLOCKS PUBLIC SPACE IN EITHT IMMORTALS PALACE AREA}

A. Verification of Coincidence Degree between Integration and Grading ${ }^{3}$

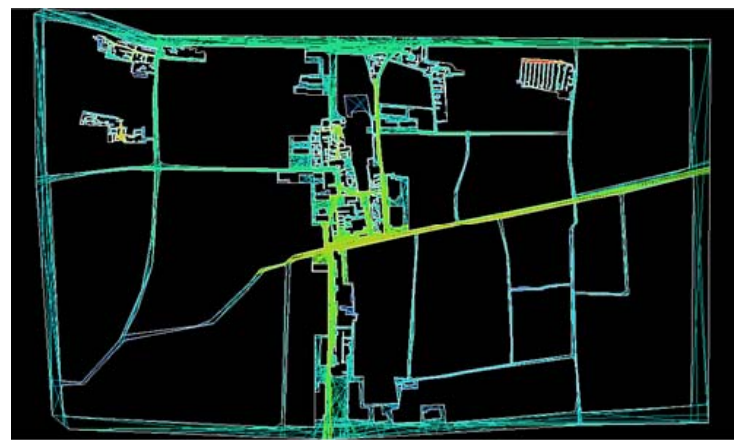

Figure 2. Integration analysis of residential area in eight immortals palace

Based on the analysis of Figure 2, all old blocks public space has district boundary with commercial land and eight immortals backward square. The integration of block four public space has three levels-from high to low. Yellow part, higher integration in the figure, is commercial land; the part ,with integration turning from yellow to green then finally to blue, is old blocks public space. The boundaries of spatial properties are very obvious with spatial relation being the dividing factor without considering boundary elements such as elevation difference, architectural form and roadblocks, etc. Considering the influence of small population, each old block is designated as residential community, and residents collection that is adjacent and is enclosed to courtyard is designated as team and group. Then the residential district structure is residential community-team and group model. ( $\leqslant$ one of three types of residential district planning structure in our country was put forward in residential design standards (2006 edition)). That result shows old blocks have a relatively open space system, and it owns the basis that the attribute of residential community space and residential area outer space turns from public to private. The analysis results of local integration degree ( $R$ $=3$ ) of seven old blocks public space Figs. 3, 6, 9, 12, 15, 18,21 ), are highly in accordance with the actual situation (Figs. 4, 5, 7, 8, 10, 11, 13, 14, 16, 17, 19, 20, 22, 23). Analysis of integration degree changes reflects difference between activity center forming by the actual use and primary-secondary road. Compared with modern residential district planning theory, space and road grading diagram show that: public space is well distributed from Block one to Block four and location of primary and secondary space is appropriate, which is higher similar with modern residential district figure; Block five and Block six show smaller space depth, which is distributed along the street; Block seven lacks public space. However, the actual observation result is within the seven old blocks, Block one to Block four have think social atmosphere, Block five and Block six are gradually turning to small shop, Block seven has many old abandoned houses that have been identified to dismantle.

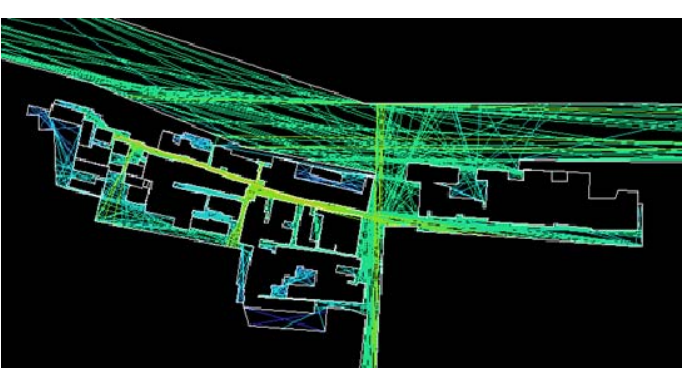

Figure 3. Integration analysis of No.1 shantytown public space

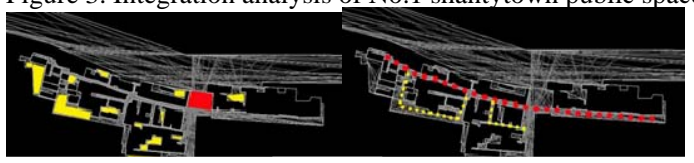

Figure 4. Public space Figure 5. Classification of roads classification in No. in No. 1 shanty town. shanty town.

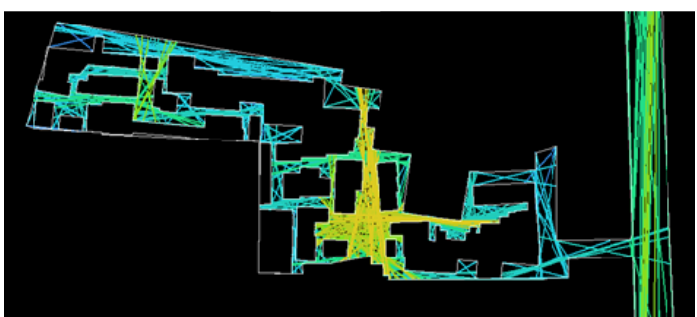

Figure 6. Integration analysis of public space in No. 2 shanty town

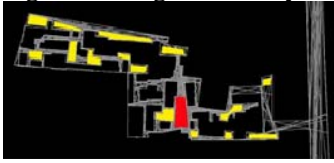

Figure 7. Public space classification in No. 2 the shanty town.

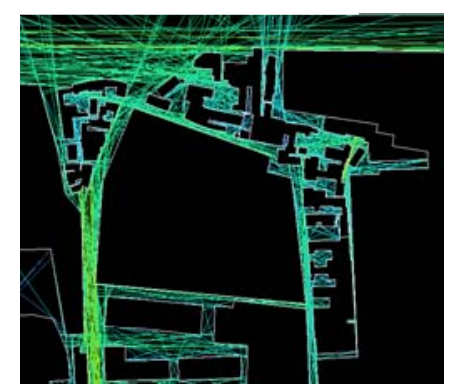

Figure 9. Integration analysis of publiı space in No. 3 shanty town

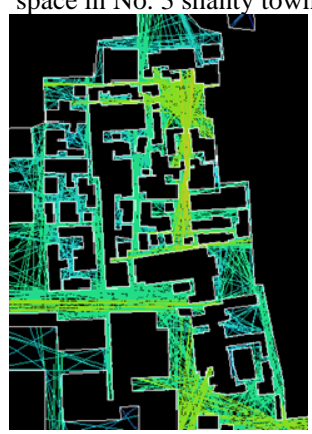

Figure 12. Integration analysisof public space in No. 4 shanty town

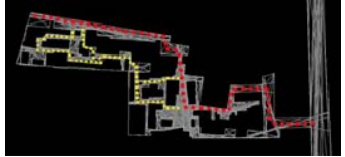

Figure 8. Classification of roads in No. 2 shanty town.

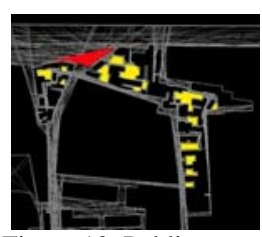

Figure 10. Public space classificationin No. 3 shanty town.

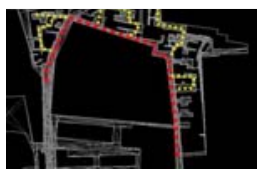

Figure 11.Classification of roads in No. 3 shanty town.

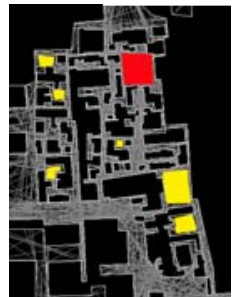

Figure 13. Public space classificatio in No. 4 shanty tow

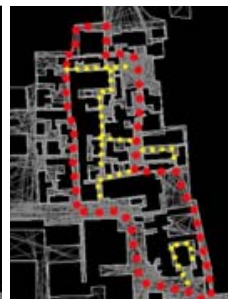

Figure 14.

Classification of roads in No.4 shanty town.

\footnotetext{
${ }^{3}$ The author put forward the noun, refers to the public space classification in shanty towns formed by actual use of frequency and the difference of the number of residents.
} 


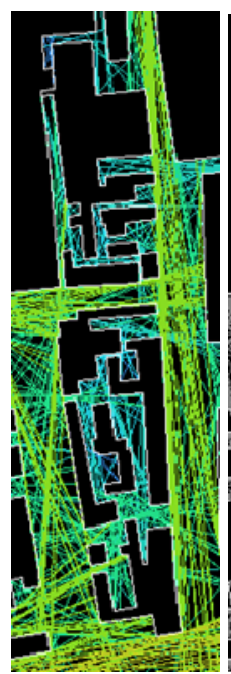

Figure 15.

Integration

analysis of

public space in

No.5 shanty

town.

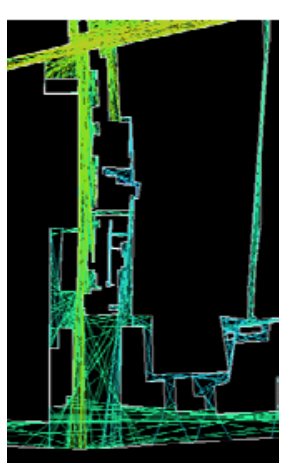

Figure 18. Integration analysis of public space in No.6 shanty town.

Figure 21. Integration analysis of public space in No. 7 shanty town.

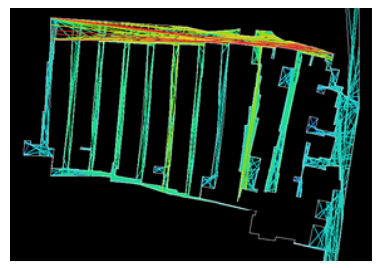

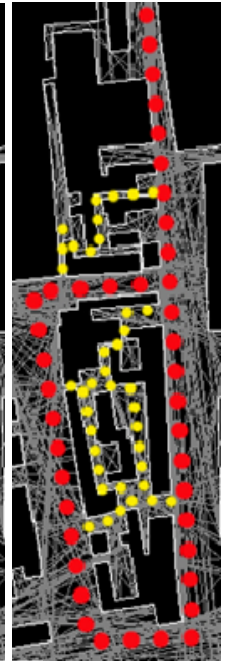

Figure 16. Public Figure 17. space Classification of classification in roads in No. 5 No. 5 shanty shanty town. town.

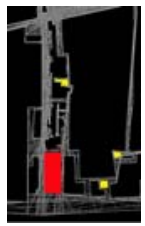

Figure 19. Public

space

classificatio

$\mathrm{n}$ in No. 6

shanty

town.

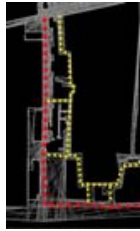

Figure 20

Classificati on of roads in No. 6 shanty town. (note: in public space grading graph, red represents community-level public space and yellow represents group-level public space. In road grading graph, red represents community-level main road, yellow represents group-level main road. Figure 2.-Figure 23. were drawn by author)

It is easy to find that public space of old blocks with self-renewal ability has formed grading patterns and has been well distributed. Early proposed points have been confirmed-the core element to determine the self-renewal of old blocks is whether public space structure can meet demands of residents' social activities or not. At the same time ,this result proves that depending on original vocabulary of old blocks to govern public space and

promoting feasibility of old blocks update are supported by instances.

\section{B. Relation between Integration and public Spatial Characteristics}

Analysis results of integration well verified that public space with different consolidation in space syntax theory own different spatial characteristics. Compared Figures 2426 with Figures 27-29, this paper shows: integration of open enlarging space is higher. Openness is public space with clear boundary, as for relation with the other public space, the open- part number is much more rather thanactual length, width, or area.

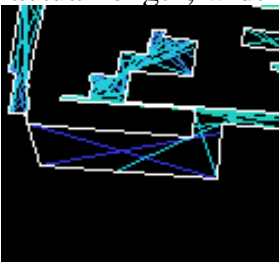

Figure 24. Enlargec space of less contac between No. 1 shant town and surroundi area.

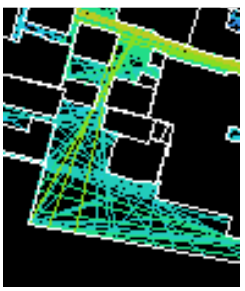

Figure 27. Enlarged space of less contact between No. 3 shanty town and surrounding area.

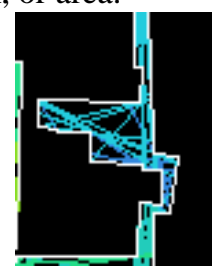

Figure 25. Enlar space of less con between No. $6 \mathrm{sh}$ town and surroun area.

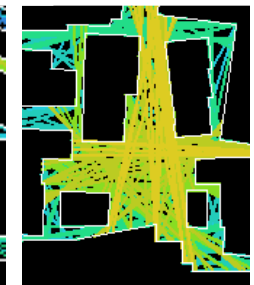

Figure 28. Enlarged space of less contact between No.2 shanty town and

surrounding area.

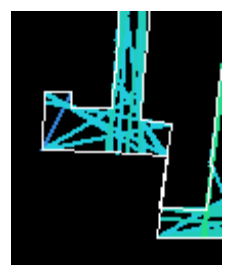

Figure 26. Enlarged space of less contact between No. 7 shanty town and surrounding area.

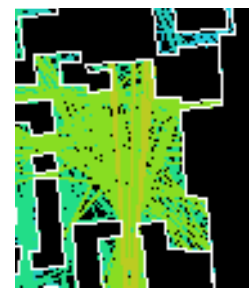

Figure 29. Enlarged space of less contact between No. 4 shanty town and

surrounding area.

Compared Figures 30, 31 with Figures 32, 33, this paper shows when public space with obvious boundary appear directional difference to another public space, the integration of all public spaces will also be affected. When most of space is in a unified coordinate direction, integration degree is relatively higher. For public space added the second direction coordinate, the integration will change obviously compared with space in the other coordinate direction. Combining field research observation, software simulation results are highly corresponding to actual situation. The role of making space integration change is to separate relatively independent new space, which is identical with limited space method in the architectural design

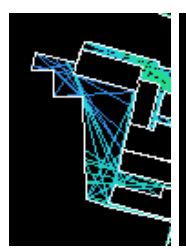

Figure 30.

Public space

with two

coordinate

directions in No.

1 shanty town.

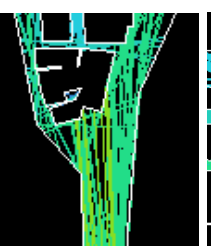

Figure 31. Public space with two coordinate directions in No. 3 shanty town.

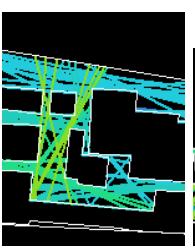

Figure 32. Public space with two coordinate

directions in No. 1 shanty town.

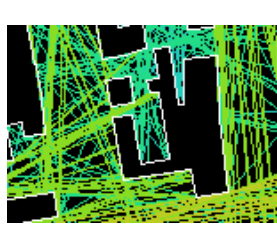

Figure 33. Public space with two coordinate directions in No. 5 shanty town. 
The shape of the space such as length-width ratio is not obviously embodied in the space syntax. But in actual using process, they have great impact on activities which can be accommodated in space, and is associated with environment behavior science in field of architectural design.

\section{PUBLIC SPACE MANAGEMENT STRATEGY OF EIGHT IMMORTALS PALACE IN OLDS BLOCKS}

It can be seen from the existing old blocks public space graph that distribution of public space is uneven and road network is obstructive. Although old blocks with space grading system have played a role in accommodating residents activities, they are not convenient and comfortable enough for residents. Urban development needs to improve livelihood of people, therefore, it is necessary to get involved in the planning management in the process of updating. Firstly, the activity space of residents in the old blocks should be increase to improve old self-renewal ability. Here we only emphasizes to ensure that the ground floor space converts into public activity space according to the need, and the space above the second floor has little relationship. This is because model simplified condition is indiscriminate breakthrough for all the space, the space on the second floor is outside the scope of research.

Secondly, public space nodes in the old blocks are arranged more even with the help of planning guidance to carry out community activities conveniently for residents. The choice for new positions of the public space can be determined after a lot of simulation comparison by using depthmap software for simulation, and then the public space integration degree can be combed under the smallest change.

Finally, it is the problem of end road. According to the residential area planning theory, the end road needs to avoid as far as possible, usually, the road network is linked into the loop road. Breaking through the road network, only one direction changes, space integration degree of the original end road will be different. Therefore, through the direction of the integration should be the road network to the space network unicom, cannot satisfy you can join the second technique such as coordinate direction, space form change guarantee space integration. In addition, it can be considered that public space nodes in old blocks are increased to connect road network in the form of enlarging the space.

\section{ACKNOWLEDGMENT}

Acknowledgements of support for the the state natural science fund of China(No.51278416);National college students' innovative training program(No.201410698083).

\section{REFERENCES}

[1] H. Bill, "Space is the machine-space fabric theory" [M]. China Building Industry Press Beijing, 2008.

[2] C. Jingmin, "Study on synthetic evaluation system of historical block based on cocial network protection and continuation." [D],South China University of Technology, Guangzhou, 2012.

[3] G. Xiang min and Q. Shui. "Space and update strategy analysis of historical and cultural blocks in Kashgar based on space syntax"[J]. Architectural Journal (S2):8-13, Beijing.

[4] L. Changtao Shenzhen pingshan village space interpretation based on space syntax[D], Harbin Industrial University, Harbin, 2011.

[5] Z. Xinyu, "Urban design method exploration based on space syntax theory-taking the overall urban design of Ji County in Tianjin as an example”[D]. Tianjin University, Tianjin.

[6] L. Jin. "Study on update protection of historical and traditional blocks of Hongyadong in Chongqing based on space syntax" $[\mathrm{J}]$. Sichuan Building Science, 2013(03):282-285.

[7] W. Chengmin and S. Yimin. "Study on the historical block protection update planning method -taking the historic district in Jiangmen city as an example” [J] Tropical Geography, 2012(02):154-159.

[8] Y. Ying. "Study on the historical commercial district space form based on space syntax" [D]. Huaqiao University, 2013.

[9] X. hong. "Some advances of contemporary social network study" [J]. Study of sociology, (3):1, Beijing, 1999.

[10] H. Bill and J. Hanson. "Social Logic of Space” Cambridge University Press, London,1984. 